\title{
PERSEPSI GURU TERHADAP PEMBELAJARAN ILMU HADITH DI SEKOLAH-SEKOLAH MENENGAH KEBANGSAAN AGAMA (SMKA) DI SARAWAK, MALAYSIA
}

\author{
Maulana Muhammad Ilyas Bin Temrin dan Mohd Akil Muhamed Ali \\ Jabatan Pengajian al-Quran dan al-Sunnah \\ Fakulti Pengajian Islam, Universiti Kebangsaan Malaysia \\ maulanailyas09@gmail.com \& akil@ukm.edu.my
}

\begin{abstract}
:
Sekolah Menengah Kebangsaan Agama (SMKA), which was originally established by the Ministry of Education in 1977 is one of the important institutions at the secondary school level in the development of Islamic studies at Malaysia. Learning the hadith, as a major part of Islamic studies, is very important because hadith is a major source of Islamic teachings. Previous studies show that there are problems that occur during the learning process hadith studies at various institutions, including at the secondary school. Therefore, this study will identify teachers' perception of learning hadith studies in school, problems that occur in the learning process and proposals to solve the problem. This study will use a questionnaire that was distributed to each of the respondents (teachers) at their respective schools. The data obtained will be processed by means of descriptive analysis of frequency, percentage, mean and standard deviation through software Statistic Package for Social Sciences (SPSS) version 23. The research findings show that the methodology of learning the hadith taught by teachers reach a high-value interpretation. However, problems occur during the learning process hadith is the lack of use of teaching aids, such as books translation of the arabic original books of hadith. Therefore, in order for the learning of hadith among these students could be improved it is necessary to update the existing syllabus, duplicate references in learning and teaching aids to reproduce the exciting and creative able to increase the interest of students in the study of hadith.
\end{abstract}

Keywords: Teachers Perceptions; Religious secondary school; Islamic Studies; the study of hadith. 


\section{Pendahuluan}

Pada era ini, masyarakat Islam khususnya di Malaysia hanya menekankan pendidikan al-Quran kepada anak-anak tanpa menjelaskan peranan hadith Rasulullah SAW yang menjadi penjelas kepada makna al-Quran tersebut. Al-Quran diturunkan dalam bahasa Arab yang mengandungi susunan ayat yang indah, unsur sastera yang tinggi, gaya bahasa yang mantap, makna yang mendalam dan meliputi segala aspek kehidupan manusia. Rasulullah SAW menjelaskan kandungannya dengan hadith Baginda. ${ }^{1}$ Oleh itu, pembelajaran ilmu hadith haruslah juga ditekankan seiring dengan pembelajaran al-Qur'an dalam kalangan masyarakat Islam khususnya golongan remaja yang bakal menjadi pemimpin umat di masa depan.

Ilmu hadith merupakan salah satu cabang ilmu yang akan dipelajari oleh setiap pelajar yang berlatarbelakangkan pengajian Islam termasuklah pelajar-pelajar yang berada di SMKA. ${ }^{2}$ Meskipun pembelajaran ilmu hadith tidak dijadikan subjek khusus, namun ianya digabungkan di dalam subjeksubjek yang lain iaitu subjek Pendidikan Syariah Islamiah (PSI) dan Pendidikan al-Quran dan al-Sunnah (PQS) di peringkat Sijil Pelajaran Malaysia (SPM) dan subjek Syariah dan Usuluddin di peringkat Sijil Tinggi Persekolahan Malaysia (S'TPM).

Pelajar Sekolah Menengah Kebangsaan Agama (SMKA) adalah di antara golongan sasaran pihak Institusi Pengajian Tinggi (IPT) untuk diserap menjadi mahasiswa di IPT tertentu khususnya dalam bidang pengajian Islam. Oleh itu, kurikulum para pelajar di sekolah tersebut haruslah mencapai tahap yang mencukupi untuk menjadi bekalan kepada para pelajar menghadapi alam universiti. Sesuai dengan tujuan utama Majlis Peperiksaan Malaysia memperkenalkan sistem peperiksaan yang baharu tersebut iaitu untuk memperbaiki orientasi pengajaran dan pembelajaran di Tingkatan 6 supaya tidak jauh berbeza dengan orientasi pengajaran di peringkat kolej dan

\footnotetext{
${ }^{1}$ Nooraini Sulaiman, Shahrulanuar Mohamed, and Sabariah Sulaiman, "Kurikulum Pendidikan Zaman Rasulullah : Pengaruhnya Terhadap Kurikulum Pendidikan Islam Masa Kini," n.d., 309-321.

${ }^{2}$ Fauzi Deraman, Ishak Hj Suliaman, and Faisal Ahmad Shah, Siri Warisan Nabawi Pengajian Hadith Di Malaysia: Tokoh, Karya Dan Institusi (Kuala Lumpur: Akademi Pengajian Islam, Universiti Malaya, 2010), hlm. 18.
} 
universiti. ${ }^{3} \mathrm{Hal}$ ini bagi memudahkan proses pembelajaran di peringkat IPT dan memberi semangat kepada para pelajar untuk lebih mendalami ilmu agama khususnya ilmu hadith.

Sekolah Menengah Kebangsaan Agama (SMKA) adalah salah satu institusi formal yang penting dalam perkembangan pengajian hadith di Malaysia. SMKA di Malaysia telah ditubuhkan sebanyak 55 buah sekolah iaitu 8 buah sekolah di Sarawak, 8 buah di Sabah dan 39 buah di Semenanjung Malaysia. Data daripada Kementerian Pendidikan Malaysia ${ }^{4}$ menunjukkan negeri yang paling banyak ditubuhkan Sekolah Menengah Kebangsaan Malaysia (SMKA) ialah negeri Sabah dan Sarawak iaitu masing-masing sebanyak 8 buah sekolah. Antara faktor tertubuhnya banyak SMKA di Sabah dan Sarawak adalah kerana luasnya negeri-negeri di kepulauan Borneo tersebut berbanding negeri-negeri lain yang terdapat di Semenanjung Malaysia. Selain itu, di Sabah dan Sarawak juga tidak banyak ditubuhkan pusat-pusat institusi khusus bidang agama seperti madrasah, sekolah pondok dan sekolah tahfiz sepertimana yang terdapat di Semenanjung Malaysia. Justeru, masyarakat di negeri Sabah dan Sarawak banyak bergantung pada SMKA untuk menghantar anak-anak belajar dalam bidang agama.

Hasil kajian lepas mendapati bahawa pengajaran hadith di Malaysia dilaksanakan, baik dalam pembelajaran formal, pembelajaran bukan formal (non-formal) dan pembelajaran tidak formal (informal). ${ }^{5}$ Di peringkat non-formal, misalnya, hasil kajian lepas mendapati bahawa pengajaran hadith di masjidmasjid pada masa kini masih menggunakan beberapa kitab utama antaranya Hadith 40 dan Riyadh al-Salihin karangan Imam Al-Nawawi, Bulugh al-Maram karangan Ibn Hajar dan Mustika Hadith terbitan Pusat Islam Jabatan Perdana Menteri. Bahkan, kitab Sahih al-Bukhari juga telah diajar di beberapa buah masjid di Malaysia. Antara masjid dan surau yang aktif dalam pengajian hadith ialah Masjid Tun Abdul Aziz Petaling Jaya Selangor yang diajar oleh Dr Abdul Sukor menggunakan kitab Sahih al-Bukhari, Masjid Sultan Haji Ahmad Shah, Universiti Islam Antarabangsa Malaysia (UIAM) yang diajar oleh Dr Muhammad Abu al-Layth al-Khayr Abadi menggunakan kitab Fath al-Bari

${ }^{3}$ Majlis Peperiksaan Malaysia, "Syariah Sukatan Pelajaran Dan Kertas Soalan Contoh," 2012, hlm. iii.

"Kementerian Pendidikan Malaysia," n.d., accessed April 3, 2017, http://www.moe.gov.my.

5Baharom Mohamad and Iliyas Hashim, Gaya Pengajaran \& Pembelajaran. Selangor (Selangor: PTS Professional Publishing Sdn. Bhd., 2010), hlm. 38. 
Syarh Sahih al-Bukhari dan Surau Muhajirin, Taman Sri Ukay yang diajar oleh Dr Mohd Asri Zainul Abidin menggunakan kitab Sahih al-Bukhari dan Riyadh al-Salihin. ${ }^{6}$

Sementara berdasarkan kajian Kamilah $^{7}$ di peringkat sarjananya mendapati bahawa kurikulum pendidikan di sekolah pondok adalah lebih tertumpu kepada ilmu-ilmu al-Naqliab iaitu yang berkaitan dengan akidah dan syariah disamping ilmu-ilmu bantu yang lain seperti tilawah al-quran, tajwid, fiqh, usul fiqh, usuluddin, hadith, mustalah al-hadith, nabu, saraf dan banyak lagi. Oleh itu, pembelajaran hadith juga turut diajar di sekolah pondok. Berdasarkan kajian-kajian lepas ${ }^{8}$ mendapati bahawa para pelajar telah didedahkan dengan kitab-kitab yang muktabar. Antara kitab hadith muktabar yang digunakan ialah al-Kutub al-Sittah, Riyadh al-Salihin, Bulugh al-Maram, al-Adhkar, Matan alArbain al-Nawawiyyah dan Matan al-Bayquniyyah.

Adapun, pendidikan formal, di Malaysia, difahami sebagai pendidikan yang tertakhluk di bawah bidang kuasa Kementerian Pendidikan Malaysia. Pendidikan formal meliputi pendidikan sekolah rendah, sekolah menengah, menengah tinggi atau prauniversiti dan pendidikan di institusi-institusi pengajian tinggi seperti universiti dan maktab. ' Pada peringkat menengah rendah iaitu bagi pelajar Tingkatan 1 hingga 3, pelajar diajar mengenai pengenalan asas tentang konsep hadith seperti pengertian hadith, hadith sebagai sumber hukum, perbezaan al-quran dan al-hadith, contoh hadith dan syarat-syarat perawi hadith. Manakala peringkat menengah atas iaitu bagi pelajar Tingkatan 4 dan 5, pelajar didedahkan dengan pengenalan al-sunnah sebagai sumber hukum, pengajian hadith dan ulum al-hadith. Pelajar lepas menengah pula iaitu pelajar Tingkatan 6 Rendah dan 6 Atas juga turut disajikan dengan pembelajaran hadith dan ulum al-badith.

Sementarak kursus-kursus yang ditawarkan dalam pengajian hadith diperingkat kolej dan universiti lebih komprehensif berbanding dengan sistem pembelajaran tradisional kerana menggabungkan antara ilmu dirayah dan riwayah. Pengajian tradisional pula hanya menekankan beberapa aspek dalam ilmu dirayah. Kepakaran dan pengalaman para pensyarah juga banyak membantu ke arah penghasilan pembelajaran hadith yang lebih bermutu dan

'Ibid, hlm. 233-238.

${ }^{7}$ Ibid, hlm. 24.

IIbid., hlm. 25-26; Deraman, Hj Suliaman, and Ahmad Shah, Siri Warisan Nabawi Pengajian Hadith Di Malaysia: Tokoh, Karya Dan Institusi, hlm. 204-207.

${ }^{9}$ Hussin, Pendidikan Di Malaysia: Sejarah, Sistem Dan Falsafah, hlm. 308. 
berkualiti. ${ }^{10}$ Fakulti Pengajian Islam adalah antara fakulti yang terawal ditubuhkan di universiti sepertimana yang berlaku di Universiti Kebangsaan Malaysia. Jabatan yang diwujudkan dalam Fakulti Pengajian Islam antaranya ialah Jabatan Pengajian al-Quran dan al-Sunnah. ${ }^{11}$

Para pelajar di Institusi Pengajian Tinggi diwajibkan untuk menghasilkan penulisan dalam bentuk latihan ilmiah atau latihan projek dalam bidang yang telah diceburi. Hal ini justeru menambahkan lagi koleksi karyakarya ilmiah dalam bidang hadith yang sangat kurang dihasilkan sebelum ini. Melalui penulisan ilmiah ini kajian-kajian baru dalam pengajian hadith dapat diterokai dan dipersembahkan untuk tatapan umum. ${ }^{12}$ Kajian-kajian lepas ini menunjukkan bahawa terdapat masalah yang berlaku sepanjang proses pembelajaran ilmu hadith di pelbagai institusi termasuklah di pesantren, pondok, universiti, masjid dan sekolah.

Kajian ini akan berfokus di SMKA yang terdapat di Sarawak sahaja. SMKA di Sarawak boleh dibahagikan kepada dua kategori utama iaitu kawasan berdekatan dengan bandar dan kawasan pedalaman. Terdapat empat SMKA yang berada di Bandar iaitu SMK Agama Sheikh Haji Othman Abdul Wahab, SMK Agama Tun Ahmad Zaidi, SMK Agama Sibu dan SMK Agama Miri. Manakala SMKA yang berada di kawasan pedalaman ialah SMK Agama Matang 2, SMK Agama Saratok, SMK Agama Igan dan SMK Agama Limbang. Hal ini justeru memudahkan masyarakat yang berada di kawasan bandar mahupun pedalaman untuk menghantar anak-anak mereka ke SMKA.

Selain itu, SMKA yang ditubuhkan juga berada di bahagian-bahagian utama di Sarawak iaitu bahagian Kuching, Saratok, Sibu, Mukah, Miri dan Limbang. Setiap sekolah memiliki pelajar bermula daripada Tingkatan 1 hingga 5. Manakala enam daripada lapan sekolah tersebut memiliki pelajar Tingkatan 6 iaitu di SMKA Sheikh Haji Othman Abdul Wahab, SMK Agama Sibu, SMK Agama Miri, SMK Agama Saratok, SMK Agama Igan dan SMK Agama Limbang. Keenam-enam sekolah tersebut menyediakan subjek Syariah dalam

10 Deraman, Hj Suliaman, and Ahmad Shah, Siri Warisan Nabawi Pengajian Hadith Di Malaysia: Tokoh, Karya Dan Institusi, hlm. 245-246.

11 Farid Mat Zain and Ibrahim Abu Bakar, "Fakulti Pengajian Islam: Sejarah Penubuhan Dan Perkembangannya," in Pembangunan Pengajian Tinggi Islam Di Malaysia, Ibrahim Abu Bakar, Muhammad Muda \& Mohammad Haji Alias (pnyt.). (Bandar Baru Nilai: Penerbit USIM Universiti Sains Islam Malaysia, 2008), 93-115.

12 Deraman, Hj Suliaman, and Ahmad Shah, Siri Warisan Nabawi Pengajian Hadith Di Malaysia: Tokoh, Karya Dan Institusi, hlm. 246. 
mata pelajaran pilihan peperiksaan STPM dan hanya dua sekolah sahaja yang menyediakan subjek Usuluddin dalam peperiksaan STPM iaitu SMK Agama Sheikh Haji Othman Abdul Wahab dan SMK Agama Sibu.

Oleh itu, kajian ini akan mengenal pasti persepsi guru terhadap pembelajaran ilmu hadith di sekolah. Selain itu, kajian ini juga akan mengenal pasti permasalahan yang berlaku dalam proses pembelajaran ilmu hadith di SMKA dan cadangan kepada penyelesaian masalah tersebut.

\section{Metode}

Kajian ini akan menggunakan instrumen soal selidik yang diedarkan kepada setiap responden (guru) di sekolah masing-masing. Data yang diperoleh akan diproses melalui kaedah analisis deskriptif kekerapan, peratusan, skor min dan sisihan piawai melalui perisian Statistic Package for Social Sciences (SPSS) version 23.

\section{Perspektif Guru Terhadap Pembelajaran Ilmu Hadith}

Populasi kajian terdiri daripada kalangan guru mata pelajaran Pendidikan Syariah Islamiah (PSI), Pendidikan al-Quran dan al-Sunnah (PQS), Syariah dan Usuluddin di semua Sekolah Menengah Kebangsaan Agama (SMKA) di Sarawak. Terdapat lapan buah SMKA yang telah dikenal pasti terdapat di Sarawak. Bilangan semua guru PSI, PQS, Syariah dan Usuluddin yang terdapat di kesemua SMKA di Sarawak ialah seramai 63 orang iaitu 25 orang guru mata pelajaran PQS, 24 orang guru mata pelajaran PSI, 9 orang guru mata pelajaran Syariah dan 5 orang guru mata pelajaran Usuluddin.

Berdasarkan jumlah guru yang telah diambil daripada setiap sekolah, jumlah guru tersebut kemudiannya dibahagikan mengikut mata pelajaran yang diajar bagi memudahkan kaedah persampelan rawak berlapis dijalankan. Bagi mendapatkan hasil kajian yang seimbang, guru-guru tersebut dipilih secara rawak dari setiap sekolah dengan bilangan yang telah ditetapkan. Selain itu, pemilihan sampel yang sedikit ini juga bagi mengelakkan keralatan pada hasil kajian kerana terdapat guru yang masih baru, bercuti dan terdapat urusan luar semasa kajian dilakukan. Penetapan bilangan guru diambil mengikut jadual Krejcie \& Morgan, ${ }^{13}$ iaitu bagi populasi seramai 63 orang adalah memadai dengan 52 orang atau lebih sampel. Oleh itu, kajian ini akan mengambil 53

13 R.V. Krejcie and Morgan D.W., "Determining Sample Size For Research Activities," Educational and Psychological Measurement, no. 30 (n.d.): 607-610. 
orang sampel sahaja sebagai responden kajian. Gambar rajah 4.1 menunjukkan kaedah persampelan berstrata yang digunakan dalam kajian ini.

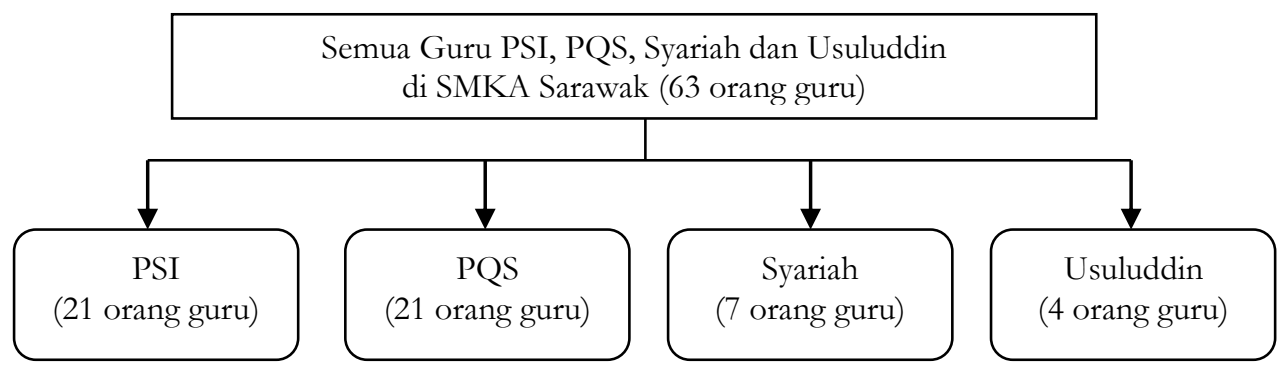

\section{Analisis Deskriptif}

Rajah 4.1 : Kaedah persampelan kajian

Analisis deskriptif kajian ini dibuat bagi menjawab kesemua objektif dalam kajian ini iaitu untuk mengenal pasti persepsi guru terhadap sukatan pelajaran ilmu hadith di peringkat SPM dan STPM, mengenal pasti metodologi pengajaran yang digunakan oleh golongan pengajar, mengenal pasti bahan bantu mengajar (BBM) yang sering digunakan dalam proses pembelajaran ilmu hadith dan mengenal pasti tahap penglibatan pelajar dalam pembelajaran ilmu hadith.

Bagi tujuan interpretasi data deskriptif kajian secara keseluruhan, dapatan kajian dianalisis berpandukan jadual 4.1 interpretasi skor min yang telah diubahsuai oleh Tobroni ${ }^{14}$ daripada jadual asal Jamil Ahmad (1993). Bagi tujuan analisis deskriptif secara lebih terperinci, data dianalisis dengan menggunakan kekerapan, peratusan, skor min dan sisihan piawai. Persetujuan responden tentang persepsi mereka terhadap pembelajaran ilmu hadith di Sekolah Menengah Kebangsaan Agama (SMKA) diperoleh dalam bentuk Skala Likert $($ Sangat tidak setuju $=$ STS, Tidak setuju $=$ TS, Tidak pasti $=$ TP, Setuju $=\mathrm{S}$, Sangat Setuju $=\mathrm{SS}$ ).

${ }_{14}$ Tobroni Bin Mohd Shahlan, "Pelaksanaan Kurikulum Pendidikan Islam Di Kolej Komuniti Kementerian Pengajian Tinggi Malaysia: Kajian Kes Di Kolej Komuniti Sabak Bernam Dan Kolej Komuniti Selayang” (Disertasi Sarjana, Fakulti Pengajian Islam, Universiti Kebangsaan Malaysia, 2010), hlm. 83. 
Jadual 4.1 Interpretasi Skor Min

\begin{tabular}{|c|c|}
\hline Skor Min & Interpretasi \\
\hline 1.00 hingga 2.33 & Rendah \\
2.34 hingga 3.66 & Sederhana \\
3.67 hingga 5.00 & Tinggi \\
\hline
\end{tabular}

Sumber : Diubahsuai oleh Tobroni (2010) dari jadual asal Jamil Ahmad (1993)

Berdasarkan jadual ini, skor min bagi 1.00 hingga 2.33 menunjukkan interpretasi yang rendah diikuti skor min 2.34 hingga 3.66 pada tahap interpretasi yang sederhana dan skor min 3.67 hingga 5.00 adalah tahap interpretasi yang tinggi. Huraian dapatan kajian ini akan dihurai berdasarkan objektif kajian.

\section{Sukatan Pelajaran Ilmu Hadith}

Jadual 4.2 menunjukkan dapatan analisis kekerapan, peratusan, skor min dan sisihan piawai bagi persepsi guru terhadap sukatan pelajaran ilmu hadith di peringkat Sijil Pelajaran Malaysia (SPM) dan Sijil Tinggi Persekolahan Malaysia (STPM). Nilai skor min secara keseluruhan persepsi guru terhadap sukatan pelajaran ilmu hadith di peringkat SPM dan STPM adalah $(\min =3.87, \mathrm{sp}=$ 0.460). Merujuk kepada jadual interpretasi skor data (jadual 4.1), tahap persepsi guru terhadap sukatan pelajaran ilmu hadith ini berada pada tahap yang tinggi. Jadual 4.2 Kekerapan, peratusan, skor min dan sisihan piawai persepsi guru terhadap sukatan pelajaran ilmu hadith di peringkat SPM dan STPM

\begin{tabular}{|c|c|c|c|c|c|c|c|c|c|}
\hline \multirow{2}{*}{$\begin{array}{l}\text { Kod } \\
\text { Item }\end{array}$} & \multirow[b]{2}{*}{ Item } & \multicolumn{6}{|c|}{ KEKERAPAN DAN PERATUSAN ( $\mathrm{N}=53$ ) } & \multirow{2}{*}{$\begin{array}{l}\text { Skor } \\
\text { Min }\end{array}$} & \multirow{2}{*}{$\begin{array}{l}\text { Sisih } \\
\text { an } \\
\text { piaw } \\
\text { ai }\end{array}$} \\
\hline & & STB & TB & TP & $S$ & SB & $\begin{array}{l}\text { Missi } \\
n g\end{array}$ & & \\
\hline $\mathrm{A} 1$ & $\begin{array}{l}\text { Adakah anda bersetuju } \\
\text { dengan struktur pelajaran } \\
\text { hadith yang terkandung di } \\
\text { dalam sukatan pelajaran }\end{array}$ & $\begin{array}{c}0 \\
(0)\end{array}$ & $\begin{array}{l}4 \\
(7 . \\
5)\end{array}$ & $\begin{array}{c}1 \\
(1.9)\end{array}$ & $\begin{array}{l}37 \\
(69 \\
.8)\end{array}$ & $\begin{array}{l}11 \\
(20 . \\
8)\end{array}$ & $\begin{array}{c}0 \\
(0)\end{array}$ & 4.04 & $\begin{array}{c}0.73 \\
3\end{array}$ \\
\hline A2 & $\begin{array}{l}\text { Sukatan pelajaran hadith } \\
\text { yang diberikan bersesuaian } \\
\text { dengan kemampuan pelajar }\end{array}$ & $\begin{array}{c}0 \\
(0)\end{array}$ & $\begin{array}{r}2 \\
(3 . \\
8)\end{array}$ & $\begin{array}{c}2 \\
(3.8)\end{array}$ & $\begin{array}{l}38 \\
(71 \\
.7)\end{array}$ & $\begin{array}{l}11 \\
(20 . \\
8)\end{array}$ & $\begin{array}{c}0 \\
(0)\end{array}$ & 4.09 & $\begin{array}{c}0.62 \\
8\end{array}$ \\
\hline A3 & $\begin{array}{l}\text { Masa yang diberikan untuk } \\
\text { mengajar adalah mencukupi } \\
\text { untuk menghabiskan } \\
\text { sukatan pelajaran hadith } \\
\text { dalam sukatan yang telah } \\
\text { diberikan }\end{array}$ & $\begin{array}{c}0 \\
(0)\end{array}$ & $\begin{array}{c}9 \\
(1 \\
7.0 \\
)\end{array}$ & $\begin{array}{c}1 \\
(1.9)\end{array}$ & $\begin{array}{l}33 \\
(62 \\
.3)\end{array}$ & $\begin{array}{c}10 \\
(18 . \\
9)\end{array}$ & $\begin{array}{c}0 \\
(0)\end{array}$ & 3.83 & $\begin{array}{c}0.93 \\
5\end{array}$ \\
\hline A4 & $\begin{array}{l}\text { Pelajar dapat memahami } \\
\text { dan menghayati pelajaran }\end{array}$ & $\begin{array}{c}0 \\
0\end{array}$ & $\begin{array}{r}4 \\
(7 .\end{array}$ & $\begin{array}{c}7 \\
(13.2)\end{array}$ & $\begin{array}{l}36 \\
(67\end{array}$ & $\begin{array}{c}6 \\
(11 .\end{array}$ & $\begin{array}{c}0 \\
(0)\end{array}$ & 3.83 & $\begin{array}{c}0.72 \\
7\end{array}$ \\
\hline
\end{tabular}




\begin{tabular}{|c|c|c|c|c|c|c|c|c|c|}
\hline & $\begin{array}{l}\text { hadith berdasarkan sukatan } \\
\text { pelajaran yang telah } \\
\text { diberikan }\end{array}$ & & 5) & & $.9)$ & 3) & & & \\
\hline A5 & $\begin{array}{l}\text { Pelajar mengenali ulamak- } \\
\text { ulamak dan kitab-kitab } \\
\text { hadith yang muktabar } \\
\text { dalam pengajian ilmu hadith }\end{array}$ & $\begin{array}{c}2 \\
(3.8 \\
)\end{array}$ & $\begin{array}{c}9 \\
(1 \\
7.0 \\
)\end{array}$ & $\begin{array}{c}17 \\
(32.1)\end{array}$ & $\begin{array}{l}22 \\
(41 \\
.5)\end{array}$ & $\begin{array}{c}3 \\
(5.7 \\
)\end{array}$ & $\begin{array}{c}0 \\
(0)\end{array}$ & 3.28 & $\begin{array}{c}0.94 \\
8\end{array}$ \\
\hline A6 & $\begin{array}{l}\text { Pelajar boleh membaca } \\
\text { matan hadith berbaris } \\
\text { dengan baik }\end{array}$ & $\begin{array}{c}0 \\
0 \\
(0)\end{array}$ & $\begin{array}{c}9 \\
(1 \\
7.0 \\
)\end{array}$ & $\begin{array}{c}9 \\
(17.0)\end{array}$ & $\begin{array}{l}31 \\
(58 \\
.5)\end{array}$ & $\begin{array}{c}4 \\
(7.5 \\
)\end{array}$ & $\begin{array}{c}0 \\
(0)\end{array}$ & 3.57 & $\begin{array}{c}0.86 \\
6\end{array}$ \\
\hline A7 & $\begin{array}{l}\text { Pelajar dapat memahami } \\
\text { peranan hadith sebagai } \\
\text { salah satu sumber rujukan } \\
\text { utama dalam Islam }\end{array}$ & $\begin{array}{c}0 \\
(0)\end{array}$ & $\begin{array}{l}1 \\
2 \\
(3 . \\
8)\end{array}$ & $\begin{array}{c}3 \\
(5.7)\end{array}$ & $\begin{array}{l}27 \\
(50 \\
.9)\end{array}$ & $\begin{array}{c}21 \\
(39 . \\
6)\end{array}$ & $\begin{array}{c}0 \\
(0)\end{array}$ & 4.26 & $\begin{array}{c}0.73 \\
8\end{array}$ \\
\hline A8 & $\begin{array}{l}\text { Saya bersetuju dengan } \\
\text { penilaian markah yang telah } \\
\text { ditetapkan dalam sukatan } \\
\text { pelajaran }\end{array}$ & $\begin{array}{c}0 \\
0 \\
(0)\end{array}$ & $\begin{array}{l}1 \\
(1 . \\
9)\end{array}$ & $\begin{array}{c}4 \\
(7.5)\end{array}$ & $\begin{array}{l}36 \\
(67 \\
.9)\end{array}$ & $\begin{array}{c}10 \\
(18 . \\
9)\end{array}$ & $\begin{array}{c}2 \\
(3.8)\end{array}$ & 4.08 & $\begin{array}{c}0.59 \\
5\end{array}$ \\
\hline A9 & $\begin{array}{l}\text { Sukatan pengajian hadith } \\
\text { yang diperuntukkan dalam } \\
\text { sukatan pelajaran adalah } \\
\text { mencukupi }\end{array}$ & $\begin{array}{c}0 \\
(0)\end{array}$ & $\begin{array}{c}6 \\
(1 \\
1.3 \\
)\end{array}$ & $\begin{array}{c}4 \\
(7.5)\end{array}$ & $\begin{array}{l}34 \\
(64 \\
.2)\end{array}$ & $\begin{array}{c}9 \\
(17 . \\
0)\end{array}$ & $\begin{array}{c}0 \\
(0)\end{array}$ & 3.87 & $\begin{array}{c}0.83 \\
3\end{array}$ \\
\hline $\mathrm{A} 10$ & $\begin{array}{l}\text { Sukatan pelajaran yang } \\
\text { telah diberikan dapat } \\
\text { membentuk keperibadian } \\
\text { dan akhlak pelajar }\end{array}$ & $\begin{array}{c}0 \\
0 \\
(0)\end{array}$ & $\begin{array}{l}1 \\
2 \\
(3 . \\
8)\end{array}$ & $\begin{array}{c}11 \\
(20.8)\end{array}$ & $\begin{array}{l}30 \\
(56 \\
.6)\end{array}$ & $\begin{array}{c}10 \\
(18 . \\
9)\end{array}$ & $\begin{array}{c}0 \\
(0)\end{array}$ & 3.91 & $\begin{array}{c}0.74 \\
1\end{array}$ \\
\hline \multicolumn{8}{|c|}{ KESELURUHAN } & 3.87 & $\begin{array}{c}0.46 \\
0\end{array}$ \\
\hline
\end{tabular}

Sumber : Soal Selidik 2017

Bagi huraian secara terperinci, didapati skor min bagi 8 daripada 10 item tersebut mencapai skor min pada tahap yang tinggi. Terdapat dua jawapan hilang (missing) yang dikenalpasti pada item A8, namun tidak mempengaruhi hasil data kajian yang telah diperolehi kerana hanya merangkumi 3.8\% daripada keseluruhan jawapan responden. Item yang mencapai skor min yang tinggi ialah item 1,2,3,4,7,8,9 dan 10. Ini bermakna kebanyakan responden kajian ini bersetuju terhadap kelapan-lapan persoalan tersebut. Manakala skor min bagi item 5 dan 6 mencapai tahap sederhana.

Berdasarkan dapatan kajian ini, bagi item yang pertama didapati $90.6 \%$ responden setuju dan sangat setuju dengan struktur pelajaran hadith yang terkandung di dalam sukatan pelajaran. Hanya $7.5 \%$ sahaja responden yang tidak setuju dan 1.9\% lagi tidak pasti dengan pernyataan tersebut. Bagi item kedua, seramai $92.5 \%$ responden setuju dan sangat setuju bahawa sukatan 
pelajaran hadith yang diberikan bersesuaian dengan kemampuan pelajar. Hanya $3.8 \%$ tidak setuju dan 3.8\% yang lain tidak pasti dengan pernyataan tersebut.

Item ketiga menunjukkan $81.2 \%$ responden setuju dan sangat setuju bahawa masa yang diberikan untuk mengajar adalah mencukupi untuk menghabiskan sukatan pelajaran hadith dalam sukatan yang telah diberikan. Hanya $17.0 \%$ sahaja yang tidak setuju dan 1.9\% lagi tidak pasti dengan pernyataan tersebut. Manakala item keempat menunjukkan $79.2 \%$ responden setuju dan sangat setuju bahawa pelajar dapat memahami dan menghayati pelajaran hadith berdasarkan sukatan pelajaran yang telah diberikan. Hanya $7.5 \%$ responden yang tidak setuju dan $13.2 \%$ yang lain tidak pasti dengan pernyataan tersebut.

Item kelima menunjukkan $47.2 \%$ responden setuju bahawa pelajar mengenali ulamak-ulamak dan kitab-kitab hadith yang muktabar dalam pengajian ilmu hadith. Hanya $20.8 \%$ responden yang tidak setuju dan sangat tidak setuju dengan pernyataan tersebut dan $32.1 \%$ responden lagi tidak pasti dengan pernyataan tersebut. Item keenam menunjukkan $66.0 \%$ responden setuju bahawa pelajar boleh membaca matan hadith berbaris dengan baik dan hanya $17.0 \%$ responden yang tidak setuju. Manakala $17.0 \%$ responden yang lain tidak pasti dengan pernyataan tersebut.

Item ketujuh menunjukkan $90.5 \%$ responden setuju dan sangat setuju bahawa pelajar dapat memahami peranan hadith sebagai salah satu sumber rujukan utama dalam Islam. Hanya 3.8\% responden tidak setuju dan 5.7\% responden yang lain tidak pasti dengan pernyataan tersebut. Item kelapan menunjukkan $86.8 \%$ responden setuju dan sangat setuju dengan penilaian markah yang telah ditetapkan dalam sukatan pelajaran. Hanya $1.9 \%$ responden tidak setuju dan $7.5 \%$ responden tidak pasti dengan pernyataan tersebut. Manakala 3.8\% responden yang lain tidak memberi jawapan dalam persoalan tersebut.

Item kesembilan menunjukkan $81.2 \%$ responden setuju dan sangat setuju bahawa sukatan pengajian hadith yang diperuntukkan dalam sukatan pelajaran adalah mencukupi. Hanya $11.3 \%$ responden tidak setuju dan $7.5 \%$ responden yang lain tidak pasti dengan pernyataan tersebut. Item kesepuluh menunjukkan $75.5 \%$ responden setuju dan sangat setuju bahawa sukatan pelajaran yang telah diberikan dapat membentuk keperibadian dan akhlak pelajar. Hanya 3.8\% responden yang tidak setuju dan 20.8\% responden yang lain tidak setuju dengan pernyataan tersebut. 
Persepsi-persepsi guru yang diperoleh dari analisis ini adalah; (A1) Adakah anda bersetuju dengan struktur pelajaran hadith yang terkandung di dalam sukatan pelajaran $(\mathrm{min}=4.04, \mathrm{sp}=0.733)$. (A2) Sukatan pelajaran hadith yang diberikan bersesuaian dengan kemampuan pelajar $(\mathrm{min}=4.09$, $\mathrm{sp}$ $=0.628$ ). (A3) Masa yang diberikan untuk mengajar adalah mencukupi untuk menghabiskan sukatan pelajaran hadith dalam sukatan yang telah diberikan $(\min =3.83, \mathrm{sp}=0.935)$. (A4) Pelajar dapat memahami dan menghayati pelajaran hadith berdasarkan sukatan pelajaran yang telah diberikan $(\mathrm{min}=$ 3.83, sp $=0.727)$. (A5) Pelajar mengenali ulamak-ulamak dan kitab-kitab hadith yang muktabar dalam pengajian ilmu hadith $(\min =3.28$, sp $=0.948)$. (A6) Pelajar boleh membaca matan hadith berbaris dengan baik $(\min =3.57, \mathrm{sp}=$ 0.866). (A7) Pelajar dapat memahami peranan hadith sebagai salah satu sumber rujukan utama dalam Islam $(\min =4.26, \mathrm{sp}=0.738)$. (A8) Saya bersetuju dengan penilaian markah yang telah ditetapkan dalam sukatan pelajaran $(\mathrm{min}=$ 4.08, sp = 0.595). (A9) Sukatan pelajarn hadith yang diperuntukkan dalam sukatan pelajaran adalah mencukupi $(\min =3.87, \mathrm{sp}=0.833)$. (A10) Sukatan pelajaran yang telah diberikan dapat membentuk keperibadian dan akhlak pelajar $(\min =3.91, \mathrm{sp}=0.741)$.

\section{Metodologi Pengajaran}

Jadual 4.3 menunjukkan dapatan analisis kekerapan, peratusan dan skor min bagi metodologi pengajaran yang digunakan oleh golongan pengajar dalam menjelaskan ilmu hadith. Nilai skor min secara keseluruhan bagi metodologi pengajaran dalam menjelaskan ilmu hadith mencapai nilai interpretasi yang tinggi iaitu $(\mathrm{min}=3.79$, $\mathrm{sp}=0.403)$.

Jadual 4.3 Kekerapan, peratusan, skor min dan sisihan piawai metodologi pengajaran dalam menjelaskan ilmu hadith

\begin{tabular}{|c|c|c|c|c|c|c|c|c|c|}
\hline \multirow{2}{*}{$\begin{array}{l}\text { Kod } \\
\text { Item }\end{array}$} & \multirow[b]{2}{*}{ Item } & \multicolumn{6}{|c|}{ KEKERAPAN DAN PERATUSAN ( $\mathrm{N}=53$ ) } & \multirow{2}{*}{$\begin{array}{l}\text { Skor } \\
\text { Min }\end{array}$} & \multirow{2}{*}{$\begin{array}{l}\text { Sisih } \\
\text { an } \\
\text { piawa } \\
\text { i }\end{array}$} \\
\hline & & STB & TB & $\mathrm{TP}$ & $S$ & SB & $\begin{array}{l}\text { Missi } \\
n g\end{array}$ & & \\
\hline B1 & $\begin{array}{l}\text { Saya menggunakan Bahasa } \\
\text { Malaysia sepenuhnya dalam } \\
\text { proses pembelajaran ilmu } \\
\text { hadith }\end{array}$ & $\begin{array}{c}0 \\
(0)\end{array}$ & $\begin{array}{c}8 \\
(15.1)\end{array}$ & $\begin{array}{c}2 \\
(3.8)\end{array}$ & $\begin{array}{c}23 \\
(43.4)\end{array}$ & $\begin{array}{c}20 \\
(37.7)\end{array}$ & $\begin{array}{c}0 \\
(0)\end{array}$ & 4.04 & 1.018 \\
\hline B2 & $\begin{array}{l}\text { Saya menggunakan Bahasa } \\
\text { Arab sepenuhnya semasa } \\
\text { proses pembelajaran ilmu } \\
\text { hadith }\end{array}$ & $\begin{array}{c}15 \\
(28.3)\end{array}$ & $\begin{array}{c}27 \\
(50.9)\end{array}$ & $\begin{array}{c}8 \\
(15.1)\end{array}$ & $\begin{array}{c}2 \\
(3.8)\end{array}$ & $\begin{array}{c}1 \\
(1.9)\end{array}$ & $\begin{array}{c}0 \\
(0)\end{array}$ & 2.00 & 0.877 \\
\hline B3 & $\begin{array}{l}\text { Saya menggunakan Bahasa } \\
\text { Arab dan Bahasa Malaysia } \\
\text { dalam proses pembelajaran } \\
\text { ilmu hadith }\end{array}$ & $\begin{array}{c}2 \\
(3.8)\end{array}$ & $\begin{array}{c}6 \\
(11.3)\end{array}$ & $\begin{array}{c}2 \\
(3.8)\end{array}$ & $\begin{array}{c}26 \\
(49.1)\end{array}$ & $\begin{array}{c}17 \\
(32.1)\end{array}$ & $\begin{array}{c}0 \\
(0)\end{array}$ & 3.94 & 1.082 \\
\hline B4 & Kaedah latihan bertulis / latih & 0 & 2 & 1 & 31 & 19 & 0 & 4.26 & 0.684 \\
\hline
\end{tabular}




\begin{tabular}{|c|c|c|c|c|c|c|c|c|c|}
\hline & $\begin{array}{l}\text { tubi menjadi pilihan saya dalam } \\
\text { proses pengajaran ilmu hadith }\end{array}$ & (0) & (3.8) & (1.9) & $(58.5)$ & $(35.8)$ & (0) & & \\
\hline B5 & $\begin{array}{l}\text { Saya menggunakan kaedah } \\
\text { pengajaran secara kuliah atau } \\
\text { syarahan semasa proses } \\
\text { pembelajaran ilmu hadith }\end{array}$ & $\begin{array}{c}0 \\
(0)\end{array}$ & $\begin{array}{c}7 \\
(13.2)\end{array}$ & $\begin{array}{c}0 \\
(0)\end{array}$ & $\begin{array}{c}37 \\
(69.8)\end{array}$ & $\begin{array}{c}8 \\
(15.1)\end{array}$ & $\begin{array}{c}1 \\
(1.9)\end{array}$ & 3.88 & 0.832 \\
\hline $\mathrm{B} 6$ & $\begin{array}{l}\text { Saya meminta pelajar untuk } \\
\text { menghafal hadith-hadith } \\
\text { tertentu dalam pembelajaran } \\
\text { ilmu hadith }\end{array}$ & $\begin{array}{c}0 \\
0 \\
(0)\end{array}$ & $\begin{array}{c}3 \\
(5.7)\end{array}$ & $\begin{array}{c}1 \\
(1.9)\end{array}$ & $\begin{array}{c}38 \\
(71.7)\end{array}$ & $\begin{array}{c}11 \\
(20.8)\end{array}$ & $\begin{array}{c}0 \\
0 \\
(0)\end{array}$ & 4.08 & 0.675 \\
\hline B7 & $\begin{array}{l}\text { Saya cenderung membuat } \\
\text { proses pengajaran ilmu hadith } \\
\text { dalam bentuk perbincangan } \\
\text { dan perkongsian bersama } \\
\text { pelajar }\end{array}$ & $\begin{array}{c}0 \\
(0)\end{array}$ & $\begin{array}{c}1 \\
(1.9)\end{array}$ & $\begin{array}{c}3 \\
(5.7)\end{array}$ & $\begin{array}{c}35 \\
(66.0)\end{array}$ & $\begin{array}{c}14 \\
(26.4)\end{array}$ & $\begin{array}{c}0 \\
(0)\end{array}$ & 4.17 & 0.612 \\
\hline B8 & $\begin{array}{l}\text { Saya sering membuat sesi soal } \\
\text { jawab dalam proses } \\
\text { pembelajaran ilmu hadith }\end{array}$ & $\begin{array}{c}0 \\
(0)\end{array}$ & $\begin{array}{c}0 \\
(0)\end{array}$ & $\begin{array}{c}0 \\
(0)\end{array}$ & $\begin{array}{c}32 \\
(60.4)\end{array}$ & $\begin{array}{c}21 \\
(39.6)\end{array}$ & $\begin{array}{c}0 \\
(0)\end{array}$ & 4.40 & 0.494 \\
\hline B9 & $\begin{array}{l}\text { Saya menggunakan kaedah } \\
\text { halaqah (lingkaran) dalam } \\
\text { proses pembelajaran ilmu } \\
\text { hadith }\end{array}$ & $\begin{array}{c}1 \\
(1.9)\end{array}$ & $\begin{array}{c}9 \\
(17.0)\end{array}$ & $\begin{array}{c}8 \\
(15.1)\end{array}$ & $\begin{array}{c}32 \\
(60.4)\end{array}$ & $\begin{array}{c}3 \\
(5.7)\end{array}$ & $\begin{array}{c}0 \\
0 \\
(0)\end{array}$ & 3.51 & 0.912 \\
\hline B10 & $\begin{array}{l}\text { Kaedah imlak juga menjadi } \\
\text { pilihan saya dalam } \\
\text { menjalankan proses } \\
\text { pengajaran ilmu hadith }\end{array}$ & $\begin{array}{c}1 \\
(1.9)\end{array}$ & $\begin{array}{c}10 \\
(18.9)\end{array}$ & $\begin{array}{c}3 \\
(5.7)\end{array}$ & $\begin{array}{c}33 \\
(62.3)\end{array}$ & $\begin{array}{c}6 \\
(11.3)\end{array}$ & $\begin{array}{c}0 \\
(0)\end{array}$ & 3.62 & 0.985 \\
\hline \multicolumn{8}{|c|}{ RUHAN } & 3.79 & 0.403 \\
\hline
\end{tabular}

Sumber : Soal Selidik 2017

Bagi huraian secara terperinci, didapati skor min bagi 7 daripada kesemua soalan pada bahagian B mencapai tahap interpretasi yang tinggi. Terdapat 1 soalan hilang (missing) yang dikenal pasti iaitu pada soalan B5, namun tidak mempengaruhi hasil data kajian kerana hanya merangkumi 1.9\% daripada keseluruhan jawapan responden. Soalan yang mencapai skor min yang tinggi ialah 1,3,4,5,6,7 dan 8. Ini bermakna kebanyakan responden kajian bersetuju terhadap ketujuh-tujuh persoalan tersebut. Terdapat 2 soalan yang mencapai tahap interpretasi yang sederhana iaitu soalan 9 dan 10. Manakala soalan 2 mencapai tahap skor min yang rendah. Ini bermakna responden kebanyakannya tidak bersetuju dengan persoalan tersebut.

Berdasarkan dapatan kajian ini, bagi item yang pertama didapati $81.1 \%$ responden setuju dan sangat setuju bahawa mereka menggunakan Bahasa Malaysia sepenuhnya dalam proses pembelajaran ilmu hadith. Hanya 15.1\% sahaja responden yang tidak setuju dan 3.8\% lagi tidak pasti dengan pernyataan tersebut. Bagi item kedua, hanya 5.7\% responden setuju dan sangat setuju bahawa mereka menggunakan Bahasa Arab sepenuhnya semasa proses pembelajaran ilmu hadith. Manakala $79.2 \%$ responden tidak setuju dan sangat 
tidak setuju dengan pernyataan tersebut. Bagi $15.1 \%$ responden yang lain tidak pasti dengan pernyataan tersebut.

Item ketiga menunjukkan $81.2 \%$ responden setuju dan sangat setuju bahawa mereka menggunakan Bahasa Arab dan Bahasa Malaysia dalam proses pembelajaran ilmu hadith. Hanya $15.1 \%$ responden sahaja yang tidak setuju dan sangat tidak setuju dengan pernyataan tersebut. Manakala 3.8\% responden lagi tidak pasti dengan pernyataan tersebut. Manakala item keempat menunjukkan 94.3\% responden setuju dan sangat setuju bahawa kaedah latihan bertulis atau latih tubi menjadi pilihan mereka dalam proses pengajaran ilmu hadith. Hanya 3.8\% responden yang tidak setuju dan 1.9\% yang lain tidak pasti dengan pernyataan tersebut.

Item kelima menunjukkan $84.9 \%$ responden setuju dan sangat setuju bahawa mereka menggunakan kaedah pengajaran secara kuliah atau syarahan semasa proses pembelajaran ilmu hadith. Hanya $13.2 \%$ responden yang tidak setuju dengan pernyataan tersebut. Manakala $1.9 \%$ responden tidak memberikan jawapan terhadap peryataan tersebut. Item keenam menunjukkan $92.5 \%$ responden setuju dan sangat setuju bahawa mereka meminta pelajar untuk menghafal hadith-hadith tertentu dalam pembelajaran ilmu hadith. Hanya $5.7 \%$ responden tidak setuju dan $1.9 \%$ responden yang lain tidak pasti dengan pernyataan tersebut.

Item ketujuh menunjukkan $92.4 \%$ responden setuju dan sangat setuju bahawa mereka cenderung membuat proses pengajaran ilmu hadith dalam bentuk perbincangan dan perkongsian bersama pelajar. Hanya 1.9\% responden tidak setuju dan $5.7 \%$ responden yang lain tidak pasti dengan pernyataan tersebut. Item kelapan menunjukkan 100\% responden setuju dan sangat setuju bahawa mereka sering membuat sesi soal jawab dalam proses pembelajaran ilmu hadith.

Item kesembilan menunjukkan $66.1 \%$ responden setuju dan sangat setuju bahawa mereka menggunakan kaedah halaqah (lingkaran) dalam proses pembelajaran ilmu hadith. Hanya $18.9 \%$ responden tidak setuju dan sangat tidak setuju dengan pernyataan tersebut. Manakala $15.1 \%$ responden yang lain tidak pasti dengan pernyataan tersebut. Item kesepuluh menunjukkan 73.6\% responden setuju dan sangat setuju bahawa kaedah imlak juga menjadi pilihan mereka dalam menjalankan proses pembelajaran ilmu hadith. Hanya 20.8\% responden yang tidak setuju dan sangat tidak setuju dengan pernyataan tersebut. Manakala 5.7\% responden yang lain tidak pasti dengan pernyataan tersebut. 
Persepsi-persepsi guru yang diperoleh dari analisis ini adalah; (B1) Saya menggunakan Bahasa Malaysia sepenuhnya dalam proses pembelajaran ilmu hadith $(\min =4.04, \mathrm{sp}=1.018)$. (B2) Saya menggunakan Bahasa Arab sepenuhnya semasa proses pembelajaran ilmu hadith $(\min =2.00, \mathrm{sp}=0.877)$. (B3) Saya menggunakan Bahasa Arab dan Bahasa Malaysia dalam proses pembelajaran ilmu hadith $(\mathrm{min}=3.94, \mathrm{sp}=1.082)$. (B4) Kaedah latihan bertulis / latih tubi menjadi pilihan saya dalam proses pengajaran ilmu hadith $(\min =4.26, \mathrm{sp}=0.684)$. (B5) Saya menggunakan kaedah pengajaran secara kuliah atau syarahan semasa proses pembelajaran ilmu hadith $(\mathrm{min}=3.88$, $\mathrm{sp}=$ 0.832). (B6) Saya meminta pelajar untuk menghafal hadith-hadith tertentu dalam pembelajaran ilmu hadith $(\min =4.08, \mathrm{sp}=0.675)$. $(\mathrm{B} 7)$ Saya cenderung membuat proses pengajaran ilmu hadith dalam bentuk perbincangan dan perkongsian bersama pelajar $(\mathrm{min}=4.17, \mathrm{sp}=0.612)$. (B8) Saya sering membuat sesi soal jawab dalam proses pembelajaran ilmu hadith $(\mathrm{min}=4.40$, $\mathrm{sp}=0.494$ ). (B9) Saya menggunakan kaedah halaqah (lingkaran) dalam proses pembelajaran ilmu hadith $(\mathrm{min}=3.51, \mathrm{sp}=0.912)$. $(\mathrm{B} 10)$ Kaedah imlak juga menjadi pilihan saya dalam menjalankan proses pengajaran ilmu hadith $(\mathrm{min}=$ 3.62, $\mathrm{sp}=0.985$.

\section{Penggunaan Bahan Bantu Mengajar (BBM)}

Jadual 4.4 menunjukkan dapatan analisis kekerapan, peratusan dan skor min bagi persepsi guru terhadap penggunaan bahan bantu mengajar (BBM) dalam proses pembelajaran ilmu hadith. Nilai skor min secara keseluruhan persepsi guru terhadap penggunaan bahan bantu mengajar (BBM) dalam pembelajaran ilmu hadith ialah $(\mathrm{min}=3.22, \mathrm{sp}=0.504$ ) iaitu pada tahap interpretasi yang sederhana.

Jadual 4.4 Kekerapan, peratusan, skor min dan sisihan piawai penggunaan bahan bantu mengajar (BMM) dalam proses pembelajaran ilmu hadith

\begin{tabular}{|c|c|c|c|c|c|c|c|c|c|}
\hline \multirow{2}{*}{$\begin{array}{l}\text { Kod } \\
\text { Item }\end{array}$} & \multirow[b]{2}{*}{ Item } & \multicolumn{6}{|c|}{ KEKERAPAN DAN PERATUSAN ( $\mathrm{N}=53$ ) } & \multirow{2}{*}{$\begin{array}{l}\text { Skor } \\
\text { Min }\end{array}$} & \multirow{2}{*}{$\begin{array}{l}\text { Sisih } \\
\text { an } \\
\text { piawa } \\
\text { i }\end{array}$} \\
\hline & & STB & TB & TP & S & SB & $\begin{array}{l}\text { Missi } \\
n g\end{array}$ & & \\
\hline $\mathrm{C} 1$ & $\begin{array}{l}\text { Bahan rujukan untuk pembelajaran ilmu } \\
\text { hadith adalah mencukupi }\end{array}$ & $\begin{array}{c}5 \\
(9.4) \\
\end{array}$ & $\begin{array}{c}22 \\
(41.5) \\
\end{array}$ & $\begin{array}{c}10 \\
(18.9)\end{array}$ & $\begin{array}{c}15 \\
(28.3) \\
\end{array}$ & $\begin{array}{c}1 \\
(1.9)\end{array}$ & $\begin{array}{c}0 \\
(0)\end{array}$ & 2.72 & 1.045 \\
\hline $\mathrm{C} 2$ & $\begin{array}{l}\text { Sekolah menyediakan bahan bantu } \\
\text { mengajar (BBM) yang mencukupi untuk } \\
\text { proses pembelajaran ilmu hadith }\end{array}$ & $\begin{array}{c}4 \\
(7.5)\end{array}$ & $\begin{array}{c}27 \\
(50.9)\end{array}$ & $\begin{array}{c}13 \\
(24.5)\end{array}$ & $\begin{array}{c}6 \\
(11.3)\end{array}$ & $\begin{array}{c}3 \\
(5.7)\end{array}$ & $\begin{array}{c}0 \\
0 \\
(0)\end{array}$ & 2.57 & 0.991 \\
\hline $\mathrm{C} 3$ & $\begin{array}{l}\text { Saya menggunakan kitab-kitab hadith } \\
\text { yang muktabar sebagai rujukan dalam } \\
\text { pembelajaran ilmu hadith }\end{array}$ & $\begin{array}{c}1 \\
(1.9)\end{array}$ & $\begin{array}{c}13 \\
(24.5)\end{array}$ & $\begin{array}{c}8 \\
(15.1)\end{array}$ & $\begin{array}{c}26 \\
(49.1)\end{array}$ & $\begin{array}{c}5 \\
(9.4)\end{array}$ & $\begin{array}{c}0 \\
(0)\end{array}$ & 3.40 & 1.025 \\
\hline $\mathrm{C} 4$ & $\begin{array}{l}\text { Saya menggunakan kemudahan ICT } \\
\text { seperti internet dan aplikasi (software) }\end{array}$ & $\begin{array}{c}0 \\
(0)\end{array}$ & $\begin{array}{c}9 \\
(17.0)\end{array}$ & $\begin{array}{c}9 \\
(17.0)\end{array}$ & $\begin{array}{c}26 \\
(49.1)\end{array}$ & $\begin{array}{c}9 \\
(17.0)\end{array}$ & $\begin{array}{c}0 \\
(0)\end{array}$ & 3.66 & 0.960 \\
\hline
\end{tabular}




\begin{tabular}{|c|c|c|c|c|c|c|c|c|c|}
\hline & $\begin{array}{l}\text { yang berkaitan dalam pembelajaran ilmu } \\
\text { hadith }\end{array}$ & & & & & & & & \\
\hline $\mathrm{C5}$ & $\begin{array}{l}\text { Saya kerap menggunakan papan hitam / } \\
\text { papan puth dalam proses P\&P }\end{array}$ & $\begin{array}{l}0 \\
(0)\end{array}$ & $\begin{array}{c}2 \\
(3.8)\end{array}$ & $\begin{array}{c}0 \\
(0)\end{array}$ & $\begin{array}{c}37 \\
(69.8)\end{array}$ & $\begin{array}{c}14 \\
(26.4)\end{array}$ & $\begin{array}{c}0 \\
(0)\end{array}$ & 4.19 & 0.622 \\
\hline C6 & $\begin{array}{l}\text { Saya kerap menggunakan buku teks / } \\
\text { buku rujukan dalam proses P\&P }\end{array}$ & $\begin{array}{l}0 \\
(0)\end{array}$ & $\begin{array}{c}1 \\
(1.9)\end{array}$ & $\begin{array}{c}1 \\
(1.9)\end{array}$ & $\begin{array}{c}34 \\
(64.2)\end{array}$ & $\begin{array}{c}17 \\
(32.1)\end{array}$ & $\begin{array}{c}0 \\
(0)\end{array}$ & 4.26 & 0.593 \\
\hline $\mathrm{C7}$ & $\begin{array}{l}\text { Saya kerap menggunakan projektor dalam } \\
\text { proses P\&P }\end{array}$ & $\begin{array}{c}1 \\
(1.9)\end{array}$ & $\begin{array}{c}16 \\
(30.2)\end{array}$ & $\begin{array}{c}8 \\
(15.1)\end{array}$ & $\begin{array}{c}24 \\
(45.3)\end{array}$ & $\begin{array}{c}4 \\
(7.5)\end{array}$ & $\begin{array}{c}0 \\
0\end{array}$ & 3.26 & 1.041 \\
\hline $\mathrm{C} 8$ & $\begin{array}{l}\text { Saya kerap menggunakan pita rakaman } \\
\text { (recorder) dalam proses P\&P }\end{array}$ & $\begin{array}{c}7 \\
(13 . \\
2)\end{array}$ & $\begin{array}{c}32 \\
(60.4)\end{array}$ & $\begin{array}{c}9 \\
(17.0)\end{array}$ & $\begin{array}{c}4 \\
(7.5)\end{array}$ & $\begin{array}{c}1 \\
(1.9)\end{array}$ & $\begin{array}{c}0 \\
(0)\end{array}$ & 2.25 & 0.853 \\
\hline C9 & $\begin{array}{l}\text { Saya kerap menggunakan alat pandang } \\
\text { dengar dalam proses } P \& P\end{array}$ & $\begin{array}{c}5 \\
(9.4) \\
\end{array}$ & $\begin{array}{c}24 \\
(45.3)\end{array}$ & $\begin{array}{c}5 \\
(9.4)\end{array}$ & $\begin{array}{c}16 \\
(30.2)\end{array}$ & $\begin{array}{c}3 \\
(5.7)\end{array}$ & $\begin{array}{c}0 \\
(0)\end{array}$ & 2.77 & 1.154 \\
\hline $\mathrm{C} 10$ & $\begin{array}{l}\text { Kaedah tradisional (tanpa BBM) adalah } \\
\text { kaedah terbaik dalam proses P\&P } \\
\text { pengajian Islam }\end{array}$ & $\begin{array}{c}4 \\
(7.5)\end{array}$ & $\begin{array}{c}17 \\
(32.1)\end{array}$ & $\begin{array}{c}6 \\
(11.3)\end{array}$ & $\begin{array}{c}19 \\
(35.8)\end{array}$ & $\begin{array}{c}7 \\
(13.2)\end{array}$ & $\begin{array}{c}0 \\
0 \\
(0)\end{array}$ & 3.15 & 1.231 \\
\hline \multicolumn{8}{|c|}{ KESELURUHAN } & 3.22 & 0.504 \\
\hline
\end{tabular}

Sumber : Soal Selidik 2017

Bagi huraian secara terperinci, didapati hanya 2 daripada semua item pada bahagian $C$ mencapai tahap interpretasi yang tinggi iaitu item 5 dan 6. Ini bermakna kebanyakan responden hanya bersetuju terhadap dua item tersebut. Pada tahap sederhana pula terdapat 7 item iaitu item 1,2,3,4,7,9 dan 10. Manakala terdapat 1 item yang mencapai skor min yang rendah iaitu item 8. Ini bermakna kebanyakan responden tidak bersetuju dengan pernyataan item tersebut.

Berdasarkan dapatan kajian ini, bagi item yang pertama didapati hanya $30.2 \%$ responden setuju dan sangat setuju bahawa bahan rujukan untuk pembelajaran ilmu hadith adalah mencukupi. Seramai 50.9\% responden tidak setuju dan sangat tidak setuju terhadap pernyataan tersebut. Manakala 18.9\% responden lagi tidak pasti dengan pernyataan tersebut. Bagi item kedua, hanya $17.0 \%$ responden setuju dan sangat setuju bahawa sekolah menyediakan bahan bantu mengajar (BBM) yang mencukupi untuk proses pembelajaran ilmu hadith. Seramai $58.4 \%$ responden setuju dan tidak setuju terhadap pernyataan tersebut. Manakala $24.5 \%$ responden yang lain tidak pasti dengan pernyataan tersebut.

Item ketiga menunjukkan $58.5 \%$ responden setuju dan sangat setuju bahawa mereka menggunakan kitab-kitab hadith yang muktabar sebagai rujukan dalam pembelajaran ilmu hadith. Hanya $26.4 \%$ responden sahaja yang tidak setuju dan sangat tidak setuju dengan pernyataan tersebut. Manakala $15.1 \%$ responden lagi tidak pasti dengan pernyataan tersebut. Item keempat menunjukkan $66.1 \%$ responden setuju dan sangat setuju bahawa mereka menggunakan kemudahan ICT seperti internet dan aplikasi (software) yang 
berkaitan dalam pembelajaran ilmu hadith. Hanya 17.0\% responden yang tidak setuju dan $17.0 \%$ yang lain tidak pasti dengan pernyataan tersebut.

Item kelima menunjukkan $96.2 \%$ responden setuju dan sangat setuju bahawa mereka kerap menggunakan papa hitam atau papan puth dalam proses P\&P. Hanya 3.8\% responden yang tidak setuju pernyataan tersebut. Item keenam menunjukkan $96.3 \%$ responden setuju dan sangat setuju bahawa mereka kerap menggunakan buku teks atau buku rujukan dalam proses P\&P. Hanya $1.9 \%$ responden yang tidak setuju dan $1.9 \%$ responden yang lain tidak pasti dengan pernyataan tersebut.

Item ketujuh menunjukkan $52.8 \%$ responden setuju dan sangat setuju bahawa mereka kerap menggunakan projektor dalam proses P\&P. Hanya $32.1 \%$ responden tidak setuju dan sangat tidak setuju dengan pernyataan tersebut. Manakala $15.1 \%$ responden yang lain tidak pasti dengan pernyataan tersebut. Item kelapan menunjukkan hanya $9.4 \%$ responden setuju dan sangat setuju bahawa mereka kerap menggunakan pita rakaman (recorder) dalam proses P\&P. Seramai $73.2 \%$ responden tidak setuju dan sangat tidak setuju dengan pernyataan tersebut. Manakala $17.0 \%$ responden yang lain tidak pasti terhadap pernyataan tersebut.

Item kesembilan menunjukkan hanya 35.9\% responden setuju dan sangat setuju bahawa mereka kerap menggunakan alat bantu dengan dalam proses P\&P. Seramai $54.7 \%$ responden tidak setuju dan sangat tidak setuju terhadap pernyataan tersebut. Manakala $9.4 \%$ responden yang lain tidak pasti dengan pernyataan tersebut. Item kesepuluh menunjukkan $49.0 \%$ responden setuju dan sangat setuju bahawa kaedah tradisional (tanpa BBM) bukanlah kaedah yang terbaik dalam proses $\mathrm{P} \& \mathrm{P}$ pengajian Islam. Hanya 39.6\% responden tidak setuju dan sangat tidak setuju terhadap pernyataan tersebut. Manakala $11.3 \%$ responden yang lain tidak pasti dengan pernyataan tersebut.

Persepsi-persepsi guru yang diperoleh dari analisis ini adalah; (C1) Bahan rujukan untuk pembelajaran ilmu hadith adalah mencukupi $(\min =2.72$, sp = 1.045). (C2) Sekolah menyediakan bahan bantu mengajar (BBM) yang mencukupi untuk proses pembelajaran ilmu hadith $(\min =2.57$, $\mathrm{sp}=0.991)$. (C3) Saya menggunakan kitab-kitab hadith yang muktabar sebagai rujukan dalam pembelajaran ilmu hadith $(\mathrm{min}=3.40, \mathrm{sp}=1.025)$. (C4) Saya menggunakan kemudahan ICT seperti internet dan aplikasi (software) yang berkaitan dalam pembelajaran ilmu hadith $(\min =3.66, \mathrm{sp}=0.960)$. (C5) Saya kerap menggunakan papan hitam / papan putih dalam proses P\&P $(\min =$ 4.19, $\mathrm{sp}=0.622)$. (C6) Saya kerap menggunakan buku teks / buku rujukan 
dalam proses $\mathrm{P} \& \mathrm{P}(\mathrm{min}=4.26, \mathrm{sp}=0.593)$. $(\mathrm{C} 7)$ Saya kerap menggunakan projektor dalam proses $\mathrm{P} \& \mathrm{P}(\mathrm{min}=3.26$, sp $=1.041)$. (C8) Saya kerap menggunakan pita rakaman (recorder) dalam proses $\mathrm{P} \& \mathrm{P}(\min =2.25, \mathrm{sp}=$ 0.853). (C9) Saya kerap menggunakan alat pandang dengar dalam proses P\&P $(\min =2.77, \mathrm{sp}=1.154) .(\mathrm{C} 10)$ Kaedah tradisional $(\operatorname{tanpa} \mathrm{BBM})$ adalah kaedah terbaik dalam proses P\&P Pengajian Islam $(\min =3.15, \mathrm{sp}=1.231)$.

\section{Penglibatan Pelajar}

Jadual 4.5 menunjukkan dapatan analisis kekerapan, peratusan, skor min dan sisihan piawai bagi penglibatan pelajar dalam mempelajari ilmu hadith. Nilai skor min secara keseluruhan persepsi guru terhadap penglibatan pelajar dalam mempelajari ilmu hadith ialah $(\min =3.03$, $\mathrm{sp}=0.765)$ iaitu pada tahap yang sederhana.

Jadual 4.5 Kekerapan, peratusan, skor min dan sisihan piawai penglibatan pelajar dalam mempelajari ilmu hadith

\begin{tabular}{|c|c|c|c|c|c|c|c|c|c|}
\hline \multirow{2}{*}{$\begin{array}{l}\text { Kod } \\
\text { Item }\end{array}$} & \multirow[b]{2}{*}{ Item } & \multicolumn{6}{|c|}{ KEKERAPAN DAN PERATUSAN (N=53) } & \multirow{2}{*}{$\begin{array}{l}\text { Skor } \\
\text { Min }\end{array}$} & \multirow{2}{*}{$\begin{array}{l}\text { Sisih } \\
\text { an } \\
\text { piawa } \\
\text { i }\end{array}$} \\
\hline & & STB & TB & TP & $\mathrm{S}$ & SB & $\begin{array}{l}\text { Missi } \\
n g\end{array}$ & & \\
\hline D1 & $\begin{array}{l}\text { Pelajar berminat dalam } \\
\text { mendalami ilmu pengajian } \\
\text { hadith }\end{array}$ & $\begin{array}{c}2 \\
(3.8)\end{array}$ & $\begin{array}{c}6 \\
(11.3)\end{array}$ & $\begin{array}{c}13 \\
(24.5)\end{array}$ & $\begin{array}{c}29 \\
(54.7)\end{array}$ & $\begin{array}{c}3 \\
(5.7)\end{array}$ & $\begin{array}{c}0 \\
(0)\end{array}$ & 3.47 & 0.912 \\
\hline D2 & $\begin{array}{l}\text { Pelajar berminat untuk } \\
\text { melibatkan diri dalam } \\
\text { perbincangan dan soal jawab } \\
\text { ketika pembelajaran ilmu hadith }\end{array}$ & $\begin{array}{c}2 \\
(3.8)\end{array}$ & $\begin{array}{c}8 \\
(15.1)\end{array}$ & $\begin{array}{c}6 \\
(11.3)\end{array}$ & $\begin{array}{c}31 \\
(58.5)\end{array}$ & $\begin{array}{c}6 \\
(11.3)\end{array}$ & $\begin{array}{c}0 \\
(0)\end{array}$ & 3.58 & 1.008 \\
\hline D3 & $\begin{array}{l}\text { Pelajar dapat membaca teks } \\
\text { Arab dengan baik walaupun } \\
\text { tanpa baris }\end{array}$ & $\begin{array}{c}11 \\
(20.8)\end{array}$ & $\begin{array}{c}21 \\
(39.6)\end{array}$ & $\begin{array}{c}14 \\
(26.4)\end{array}$ & $\begin{array}{c}6 \\
(11.3)\end{array}$ & $\begin{array}{c}1 \\
(1.9)\end{array}$ & $\begin{array}{c}0 \\
(0)\end{array}$ & 2.34 & 0.999 \\
\hline D4 & $\begin{array}{l}\text { Pelajar boleh memahami teks } \\
\text { hadith walaupun ditulis dalam } \\
\text { bahasa Arab }\end{array}$ & $\begin{array}{c}9 \\
(17.0)\end{array}$ & $\begin{array}{c}22 \\
(41.5)\end{array}$ & $\begin{array}{c}12 \\
(22.6)\end{array}$ & $\begin{array}{c}9 \\
(17.0)\end{array}$ & $\begin{array}{c}1 \\
(1.9)\end{array}$ & $\begin{array}{c}0 \\
(0)\end{array}$ & 2.45 & 1.030 \\
\hline D5 & $\begin{array}{l}\text { Pelajar boleh menghafal hadith } \\
\text { yang telah dipelajari }\end{array}$ & $\begin{array}{c}1 \\
(1.9)\end{array}$ & $\begin{array}{c}10 \\
(18.9)\end{array}$ & $\begin{array}{c}10 \\
(18.9)\end{array}$ & $\begin{array}{c}28 \\
(52.8)\end{array}$ & $\begin{array}{c}3 \\
(5.7)\end{array}$ & $\begin{array}{c}1 \\
(1.9)\end{array}$ & 3.42 & 0.936 \\
\hline D6 & $\begin{array}{l}\text { Pelajar dapat menghuraikan } \\
\text { matan hadith dengan baik }\end{array}$ & $\begin{array}{c}4 \\
(7.5)\end{array}$ & $\begin{array}{c}17 \\
(32.1)\end{array}$ & $\begin{array}{c}7 \\
(13.2)\end{array}$ & $\begin{array}{c}23 \\
(43.4)\end{array}$ & $\begin{array}{c}2 \\
(3.8)\end{array}$ & $\begin{array}{c}0 \\
(0)\end{array}$ & 3.04 & 1.109 \\
\hline D7 & $\begin{array}{l}\text { Pelajar dapat menguasai istilah- } \\
\text { istilah yang terdapat dalam ilmu } \\
\text { hadith }\end{array}$ & $\begin{array}{c}2 \\
(3.8)\end{array}$ & $\begin{array}{c}17 \\
(32.1)\end{array}$ & $\begin{array}{c}11 \\
(20.8)\end{array}$ & $\begin{array}{c}21 \\
(39.6)\end{array}$ & $\begin{array}{c}1 \\
(1.9)\end{array}$ & $\begin{array}{c}1 \\
(1.9)\end{array}$ & 3.04 & 0.989 \\
\hline D8 & $\begin{array}{l}\text { Pelajar mengenali ulamak- } \\
\text { ulamak yang masyhur dalam } \\
\text { bidang pengajian Islam }\end{array}$ & $\begin{array}{c}4 \\
(7.5)\end{array}$ & $\begin{array}{c}13 \\
(24.5)\end{array}$ & $\begin{array}{c}15 \\
(28.3)\end{array}$ & $\begin{array}{c}19 \\
(35.8)\end{array}$ & $\begin{array}{c}1 \\
(1.9)\end{array}$ & $\begin{array}{c}1 \\
(1.9)\end{array}$ & 3.00 & 1.010 \\
\hline D9 & $\begin{array}{l}\text { Pelajar mengenal kitab-kitab } \\
\text { yang muktabar dalam pengajian } \\
\text { ilmu hadith }\end{array}$ & $\begin{array}{c}5 \\
(9.4)\end{array}$ & $\begin{array}{c}15 \\
(28.3)\end{array}$ & $\begin{array}{c}17 \\
(32.1)\end{array}$ & $\begin{array}{c}14 \\
(26.4)\end{array}$ & $\begin{array}{c}1 \\
(1.9)\end{array}$ & $\begin{array}{c}1 \\
(1.9)\end{array}$ & 2.83 & 1.004 \\
\hline D10 & $\begin{array}{l}\text { Pelajar mendapat keputusan } \\
\text { yang memberangsangkan } \\
\text { dalam pengajian hadith ketika } \\
\text { peperiksaan diadakan }\end{array}$ & $\begin{array}{c}2 \\
(3.8)\end{array}$ & $\begin{array}{c}15 \\
(28.3)\end{array}$ & $\begin{array}{c}11 \\
(20.8)\end{array}$ & $\begin{array}{c}24 \\
(45.3)\end{array}$ & $\begin{array}{c}1 \\
(1.9)\end{array}$ & $\begin{array}{c}0 \\
(0)\end{array}$ & 3.13 & 0.981 \\
\hline
\end{tabular}


Bagi huraian secara terperinci, didapati skor min bagi kesemua soalan mencapai tahap interpretasi yang sederhana. Terdapat satu jawapan hilang (missing) yang dikenal pasti pada empat soalan iaitu soalan 5,7,8 dan 9. Namun ianya tidak mempengaruhi hasil data kajian kerana hanya merangkumi 1.9\% daripada keseluruhan jawapan responden. Keseluruhan jawapan mencapai tahap interpretasi yang sederhana, ini menunjukkan para responden memberi pendapat bahawa penglibatan pelajar dalam pembelajaran ilmu hadith adalah pada tahap yang sederhana.

Berdasarkan dapatan kajian ini, bagi item yang pertama didapati seramai $60.4 \%$ responden setuju dan sangat setuju bahawa pelajar berminat dalam mendalami ilmu pengajian hadith. Hanya $15.1 \%$ responden tidak setuju dan sangat tidak setuju terhadap pernyataan tersebut. Manakala 24.5\% responden lagi tidak pasti dengan pernyataan tersebut. Bagi item kedua, seramai 69.8\% responden setuju dan sangat setuju bahawa pelajar berminat untuk melibatkan diri dalam perbincangan dan soal jawab ketika pembelajaran ilmu hadith. Hanya $18.9 \%$ responden tidak setuju dan sangat tidak setuju terhadap pernyataan tersebut. Manakala $11.3 \%$ responden yang lain tidak pasti dengan pernyataan tersebut.

Item ketiga menunjukkan hanya $13.2 \%$ responden setuju dan sangat setuju bahawa pelajar dapat membaca teks hadith dengan baik walaupun tanpa baris. Seramai $60.4 \%$ responden tidak setuju dan sangat tidak setuju dengan pernyataan tersebut. Manakala $26.4 \%$ responden lagi tidak pasti dengan pernyataan tersebut. Item keempat menunjukkan hanya 18.9\% responden setuju dan sangat setuju bahawa pelajar boleh memahami teks hadith walaupun ditulis dalam Bahasa Arab. Seramai 58.5\% responden yang tidak setuju dan sangat tidak setuju dengan pernyataan tersebut. Manakala 22.6\% responden yang lain tidak pasti dengan pernyataan tersebut.

Item kelima menunjukkan $58.5 \%$ responden setuju dan sangat setuju bahawa pelajar boleh menghafal hadith yang telah dipelajari. Hanya 20.8\% responden yang tidak setuju dan sangat tidak setuju dengan pernyataan tersebut. Manakala $18.9 \%$ responden lagi tidak pasti dengan pernyataan tersebut dan terdapat $1.9 \%$ responden yang tidak memberi jawapan terhadap pernyataan tersebut. Item keenam menunjukkan $47.2 \%$ responden setuju dan sangat setuju bahawa pelajar dapat menghuraikan matan hadith dengan baik. Hanya 39.6\% responden tidak setuju dan sangat tidak setuju dengan 
pernyataan tersebut. Manakala $13.2 \%$ responden yang lain tidak pasti dengan pernyataan tersebut.

Item ketujuh menunjukkan $41.5 \%$ responden setuju dan sangat setuju bahawa pelajar dapat menguasai istilah-istilah yang terdapat dalam ilmu hadith. Hanya $35.9 \%$ responden tidak setuju dan sangat tidak setuju dengan pernyataan tersebut. Manakala 20.8\% responden yang lain tidak pasti dengan pernyataan tersebut dan terdapat $1.9 \%$ responden yang tidak memberi jawapan terhadap pernyataan tersebut. Item kelapan menunjukkan $37.7 \%$ responden setuju dan sangat setuju bahawa pelajar mengenali ulamak-ulamak yang masyhur dalam bidang pengajian Islam. Manakala 32.0\% responden tidak setuju dan sangat tidak setuju dengan pernyataan tersebut. Seramai $28.5 \%$ responden yang lain tidak pasti terhadap pernyataan tersebut dan terdapat $1.9 \%$ responden yang tidak memberi jawapan terhadap pernyataan tersebut.

Item kesembilan menunjukkan hanya $28.3 \%$ responden setuju dan sangat setuju bahawa pelajar mengenal kitab-kitab yang muktabar dalam pengajian ilmu hadith. Seramai $37.7 \%$ responden tidak setuju dan sangat tidak setuju terhadap pernyataan tersebut. Manakala $32.1 \%$ responden yang lain tidak pasti dengan pernyataan tersebut dan terdapat $1.9 \%$ responden yang tidak memberi jawapan terhadap pernyataan tersebut. Item kesepuluh menunjukkan $47.2 \%$ responden setuju dan sangat setuju bahawa pelajar mendapat keputusan yang memberangsangkan dalam pengajian hadith ketika peperiksaan diadakan. Hanya $32.1 \%$ responden tidak setuju dan sangat tidak setuju terhadap pernyataan tersebut. Manakala $20.8 \%$ responden yang lain tidak pasti dengan pernyataan tersebut.

Persepsi-persepsi guru yang diperoleh dari analisis ini adalah; (D1) Pelajar berminat dalam mendalami ilmu pengajian hadith $(\min =3.47, \mathrm{sp}=$ 0.912). (D2) Pelajar berminat untuk melibatkan diri dalam perbincangan dan soal jawab ketika pembelajaran ilmu hadith $(\min =3.58, \mathrm{sp}=1.008)$. (D3) Pelajar dapat membaca teks Arab dengan baik awalaupun tanpa baris (min = 2.34, $\mathrm{sp}=0.999)$. (D4) Pelajar boleh memahami teks hadith walaupun ditulis dalam bahasa Arab $(\min =2.45, \mathrm{sp}=1.030)$. (D5) Pelajar boleh menghafal hadith yang telah dipelajari $(\mathrm{min}=3.42, \mathrm{sp}=0.936)$. (D6) Pelajar dapat menghuraikan matan hadith dengan baik $(\min =3.04, \mathrm{sp}=1.109)$. (D7) Pelajar dapat menguasai istilah-istilah yang terdapat dalam ilmu hadith $(\mathrm{min}=3.04$, sp $=0.989$ ). (D8) Pelajar mengenali ulamak-ulamak yang masyhur dalam bidang pengajian Islam $(\min =3.00, \mathrm{sp}=1.010)$. (D9) Pelajar mengenal kitab-kitab yang muktabar dalam pengajian ilmu hadith $(\min =2.83, \mathrm{sp}=1.004) .(\mathrm{D} 10)$ 
Pelajar mendapat keputusan yang memberangsangkan dalam pengajian hadith ketika peperiksaan diadakan $(\min =3.13, \mathrm{sp}=0.981)$.

\section{Perbandingan Skor Min Bagi Setiap Pemboleh Ubah}

Rajah 4.2 menunjukkan perbandingan skor min dan sisihan piawai secara keseluruhan setiap pemboleh ubah dalam kajian ini. Persepsi guru terhadap sukatan pelajaran memberikan skor min yang paling tinggi dalam kajian ini $(\mathrm{min}=3.87, \mathrm{sp}=0.460)$ diikuti skor min metodologi pengajaran iaitu sebanyak (min 3.79, $\mathrm{sp}=0.403$ ). Kedua-dua pemboleh ubah ini mencapai interpretasi yang tinggi. Manakala pemboleh ubah yang menghasilkan nilai skor min yang ketiga tinggi ialah penggunaan bahan bantu mengajar (BBM) dengan skor min sebanyak $(\min =3.22, \mathrm{sp}=0.504)$ dan yang terakhir ialah pemboleh ubah penglibatan pelajar iaitu dengan skor min sebanyak $(\min =3.03, \mathrm{sp}=$ 0.504). Kedua-dua pemboleh ubah tersebut mencapai interpretasi pada tahap yang sederhana.

Rajah 4.2 Nilai Skor Min Bagi Semua Pemboleh Ubah Kajian



\section{Permasalahan dan Cadangan}

Rujukan : Soal Selidik 2017

Dapatan ini adalah hasil dari soalan terbuka pada bahagian $\mathrm{C}$ borang soal selidik kajian. Soalan ini dibuat bertujuan untuk mendapatkan maklumat tentang permasalahan yang sering dihadapi oleh para guru ketika proses pembelajaran ilmu hadith dan cadangan para guru untuk memperbaiki dan mengembangkan lagi sistem pembelajaran ilmu hadith terutama di peringkat SPM dan STPM. Seramai 52 daripada 53 orang responden memberikan jawapan bagi permasalahan yang berlaku. Manakala bahagian cadangan 
mendapati seramai 49 daripada 53 orang responden memberikan cadangan bagi penambahbaikan sistem pembelajaran ilmu hadith. Oleh itu, dapatan kajian ini akan dibahagikan mengikut pemboleh ubah kajian iaitu sukatan pelajaran, metodologi pengajaran, bahan bantu mengajar (BBM) dan penglibatan pelajar.

\section{Sukatan Pelajaran}

Hasil dapatan kajian menunjukkan hanya 2 orang (3.8\%) responden sahaja yang menyatakan permasalahan berlaku pada bahagian sukatan pelajaran. Permasalahan yang dinyatakan ialah pecahan topik yang banyak menyebabkan pemahaman pelajar yang pelbagai dan masalah skop pembelajaran ilmu hadith dalam subjek Pendidikan Syariah Islamiah (PSI) adalah terhad.

Bahagian cadangan menunjukkan seramai 22 orang $(41.5 \%)$ responden telah memberikan jawapan bagi bahagian sukatan pelajaran. Jawapan yang paling banyak ialah meminta kepada pihak KPM untuk mengemaskini sukatan pelajaran yang sedia ada dengan memperluaskan skop perbincangan ilmu hadith. Hanya sebahagian kecil yang meminta untuk mengurangkan sukatan ilmu hadith dan mempelajari bab-bab hadith yang mudah sahaja. Cadangan yang lain ialah menjadikan subjek PSI, PQS, Syariah dan Usuluddin sebagai subjek wajib lulus. Selain itu, terdapat juga cadangan untuk mewujudkan subjek khusus pengajian hadith. Sebahagian kecil responden mencadangkan untuk menukar sistem peperiksaan SPM yang mewajibkan penulisan jawi dalam peperiksaan kepada tidak wajib kerana sebahagian pelajar lemah dalam penulisan jawi. Hanya seorang responden yang meminta untuk menambahkan masa pengajaran dan pembelajaran kerana masa yang tidak mencukupi untuk menghabiskan silibus pelajaran.

\section{Metodologi Pengajaran}

Bagi bahagian metodologi pengajaran, terdapat 3 orang $(5.7 \%)$ responden telah memberikan kenyataan tentang masalah yang berlaku semasa proses pembelajaran ilmu hadith. Komen tentang masalah dalam metodologi pengajaran ialah terdapat guru yang kurang berpengalaman. Selain itu, pelajar juga kurang didedahkan dengan sumber-sumber rujukan luar dan hanya belajar berpandukan buku teks. Masalah yang lain ialah tiada iklan yang menggalakkan para pelajar untuk mempelajari hadith.

Manakala cadangan dalam aspek metodologi pengajaran pula terdapat 14 orang $(26.4 \%)$ responden yang telah memberikan jawapan. Cadangan yang paling banyak ialah cadangan untuk menyediakan kursus kepada para guru bagi memberi kemahiran dalam pengurusan P\&P pengajian ilmu hadith. Cadangan yang lain ialah menggunakan teknik pengajaran yang menarik dan kreatif. Selain 
itu, para guru perlu menggalakkan pelajar menghafal dan memahami matan hadith. Terdapat juga cadangan untuk menyediakan guru yang khusus dalam pengajian hadith.

\section{Bahan Bantu Mengajar (BBM)}

Dapatan kajian menunjukkan seramai 10 orang $(18.9 \%)$ telah memberikan jawapan tentang masalah yang berlaku melibatkan penggunaan bahan bantu mengajar (BBM) dalam proses P\&P. Masalah yang paling banyak dinyatakan ialah masalah kekurangan bahan rujukan seperti buku-buku terjemahan dari kitab hadith yang muktabar. Masalah lain ialah masalah kekurangan bahan bantu mengajar (BBM) yang membantu dalam proses P\&P.

Cadangan para responden melibatkan penggunaan bahan bantu mengajar (BBM) terdapat 22 orang $(41.5 \%)$ yang telah memberikan respon. Cadangan yang paling banyak ialah untuk memperbanyakkan bahan rujukan bahan rujukan dan buku teks khusus dalam pengajian hadith. Cadangan lain ialah para guru haruslah menggunakan BBM yang bersesuaian dan menarik dalam proses P\&P. Selain itu, terdapat sebahagian kecil responden yang mencadangkan untuk menyediakan modul khas berkaitan pengajian hadith.

\section{Penglibatan Pelajar}

Masalah yang paling banyak dinyatakan oleh responden ialah melibatkan penglibatan pelajar dalam proses P\&P iaitu komen daripada 43 orang $(81.1 \%)$ responden. Masalah yang paling banyak dilaporkan ialah pelajar lemah dan malas dalam menghafal, memahami dan menghayati hadith Rasulullah SAW. Selain itu, pelajar juga kurang berminat dalam pembelajaran kerana subjek yang sukar dan terdapat sebahagian pelajar yang terpaksa belajar atas desakan keluarga. Masalah lain yang melibatkan pelajar ialah pelajar lemah dalam bahasa Arab dan penulisan jawi. Masalah lain yang melibatkan penglibatan pelajar juga adalah kurangnya kesedaran para pelajar tentang masa depan Pengajian Islam.

Terdapat 9 orang $(17.0 \%)$ responden yang telah memberikan jawapan tentang cadangan melibatkan penglibatan pelajar dalam pembelajaran ilmu hadith. Cadangan yang paling banyak ialah untuk semaikan minat agar pelajar betul-betul ingin mendalami ilmu hadith. Selain itu, terdapat juga cadangan untuk memberi motivasi dan pendedahan kepada pelajar tentang kepentingan pengajian agama. Pelajar juga perlu diterapkan dengan sunnah Rasulullah SAW dalam kehidupan harian mereka. Cadangan lain ialah pelajar juga perlu dipupuk untuk mencintai Bahasa Arab agar dapat memahami isi kandungan hadith dengan tepat. 


\section{Simpulan}

Sistem pembelajaran yang sistematik mampu merealisasikan hasrat Kementerian Pendidikan Malaysia yang ingin melahirkan para pelajar yang berketerampilan sebagai pemimpin yang diteladani. Hasrat kerajaan untuk melahirkan pelajar yang berketerampilan pastinya seiring dengan kehendak masyarakat tempatan khususnya golongan ibu bapa dan guru-guru. Oleh itu, persepsi para guru haruslah diteliti kerana para guru adalah insan yang paling mengenali anak muridnya.

Secara umumnya kajian ini mendapati bahawa persepsi guru terhadap sukatan pelajaran dan metodologi pengajaran ilmu hadith peringkat SPM dan STPM berdasarkan skor min yang diperoleh mencapai tahap interpretasi yang tinggi. Ini menunjukkan bahawa para guru bersetuju dengan sukatan pelajaran dan metodologi pengajaran yang telah digunakan. Manakala persepsi guru terhadap penggunaan bahan bantu mengajar (BBM) dan penglibatan pelajar sepanjang proses P\&P pengajian ilmu hadith hanya mencapai tahap sederhana. Ini menunjukkan bahawa penggunaan BBM dan penglibatan pelajar dalam pengajian ilmu hadith masih di tahap sederhana.

Aduan masalah dan cadangan para guru haruslah diambil serius bagi memudahkan proses pengajaran dan pembelajaran di sekolah. Permasalahan yang dihadapi oleh para guru di SMKA ialah sikap para pelajar yang lemah, malas dan kurang penghayatan dalam pembelajaran ilmu hadith di samping kekurangan bahan bantu mengajar (BBM) dalam proses pembelajaran. Masalah ini dapat dibantu dengan mengemaskini sukatan pelajaran yang sedia ada dan memperbanyakkan bahan rujukan dalam pembelajaran. Selain itu, penggunaan bahan bantu mengajar (BBM) yang menarik dan kreatif mampu meningkatkan minat para pelajar untuk lebih mendalami ilmu-ilmu Islam termasuk pengajian ilmu hadith.

Kesimpulannya, sistem pembelajaran yang sistematik dan bantuan BBM yang pelbagai mampu memberi kesan kepada penglibatan pelajar dalam aktiviti pembelajaran. Oleh itu, semua pihak harus berusaha memperbaiki dan mempertingkatkan kemudahan sekolah supaya dapat meningkatkan penglibatan pelajar dalam proses pembelajaran dan meningkatkan mutu pendidikan khususnya dalam Pengajian Islam. 


\section{Daftar Pustaka}

Deraman, Fauzi, Ishak Hj Suliaman, and Faisal Ahmad Shah. Siri Warisan Nabawi Pengajian Hadith Di Malaysia: Tokoh, Karya Dan Institusi. Kuala Lumpur: Akademi Pengajian Islam, Universiti Malaya, 2010.

Hussin, Sufean. Pendidikan Di Malaysia: Sejarah, Sistem Dan Falsafah. Kuala Lumpur: Dewan Bahasa dan Pustaka, 1993.

Kamus Dewan. Kuala Lumpur: Dewan Bahasa dan Pustaka.

Kementerian Pelajaran Malaysia. Pelan Pembangunan Pendidikan Malaysia 20132025 (Pendidikan Prasekolah Hingga Lepas Menengah). Putrajaya Malaysia: Kementerian Pendidikan Malaysia, 2013.

"Kementerian Pendidikan Malaysia," accessed April 3, 2017. http://www.moe.gov.my.

Krejcie, R.V., and Morgan D.W. "Determining Sample Size For Research Activities." Educational and Psychological Measurement, no. 30 (n.d.): 607610.

Majlis Peperiksaan Malaysia. "Syariah Sukatan Pelajaran Dan Kertas Soalan Contoh," 2012.

Mat Zain, Farid, and Ibrahim Abu Bakar. "Fakulti Pengajian Islam: Sejarah Penubuhan Dan Perkembangannya." In Pembangunan Pengajian Tinggi Islam Di Malaysia, 93-115. Ibrahim Abu Bakar, Muhammad Muda \& Mohammad Haji Alias (pnyt.). Bandar Baru Nilai: Penerbit USIM Universiti Sains Islam Malaysia, 2008.

Mohamad, Baharom, and Iliyas Hashim. Gaya Pengajaran \& Pembelajaran. Selangor. Selangor: PTS Professional Publishing Sdn. Bhd., 2010.

Mohamed, Kamilah Binti. "Persepsi Pelajar Terhadap Pendekatan Pengajaran Di Sekolah Pondok: Kajian Kes Di Sekolah Pondok Addiniyah Badriah, Pasir Tumbuh, Kota Bharu, Kelantan." Projek Penyelidikan Sarjana, Fakulti Pendidikan, Universiti Kebangsaan Malaysia, 2000.

Mohd Shahlan, Tobroni Bin. "Pelaksanaan Kurikulum Pendidikan Islam Di Kolej Komuniti Kementerian Pengajian Tinggi Malaysia: Kajian Kes Di Kolej Komuniti Sabak Bernam Dan Kolej Komuniti Selayang." Disertasi Sarjana, Fakulti Pengajian Islam, Universiti Kebangsaan Malaysia, 2010.

Rukmana, Nana. Masjid Dan Dakwah : Merencanakan, Membangun, Dan Mengelola Masjid: Mengemas Substansi Dakwah, Upaya Pemecahan Krisis Moral Dan Spiritual. Jakarta: Al-Mawardi Prima, 2002. 
Sulaiman, Nooraini, Shahrulanuar Mohamed, and Sabariah Sulaiman. "Kurikulum Pendidikan Zaman Rasulullah: Pengaruhnya Terhadap Kurikulum Pendidikan Islam Masa Kini.” 309-321, n.d. 